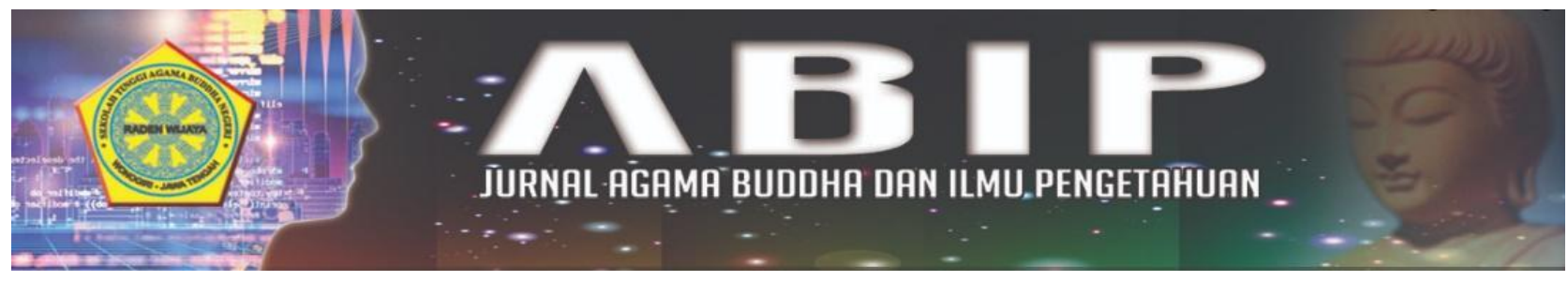

\title{
ANALISIS PERILAKU NARSISTIK REMAJA BUDDHIS PENGGUNA APLIKASI TIKTOK DI DESA MOJOREJO, KECAMATAN JUNREJO
}

\author{
Kurniati \\ Sekolah Tinggi Agama Buddha Kertarajasa \\ kurniatimisdi5@gmail.com
}

\begin{abstract}
Abstrak
Remaja memiliki rasa keingintahuan dan pencarian jati diri dengan menampilkan perilaku narsistik untuk diakui di masyarakat. Narsistik ditampilkan melalui media sosial salah satunya aplikasi TikTok. Tujuan penelitian ini mengetahui sebab penggunaan dan dampak aplikasi TikTok dan keterkaitan penggunaan aplikasi TikTok dengan perilaku narsistik remaja Buddhis. Metode dalam penelitian ini adalah deskriptif kualitatif dan sumber data primer diperoleh melalui observasi, wawancara dan dokumentasi. Hasil dari penelitian ini menunjukkan bahwa penggunaan aplikasi TikTok oleh remaja Buddhis di Desa Mojorejo disebabkan; hiburan, mencari informasi dan mengikuti jaman. Dampak positif aplikasi TikTok yakni, percaya diri, aktif, menambah pengetahuan. Disamping itu, dampak negatif yang timbul kesulitan mengatur waktu, munculnya rasa malas, dan kesulitan mengontrol emosi. Perilaku narsistik ditunjukkan remaja Buddhis dari keinginan memiliki banyak followers, dan agresi sebagai respon ketika mendapat teguran.
\end{abstract}

Kata kunci: Remaja Buddhis, Narsistik, TikTok

\begin{abstract}
Teenager has a sense of curiosity and a search for identity by displaying narcissistic behavior to be recognized in society. Narcissism is displayed through social media, one of which is the TikTok application. The purpose of this study is to find out the causes and effects of the use and impact of the TikTok application and the relationship between the use of the TikTok application and the narcissistic behavior of Buddhist adolescents. The method in this study is descriptive qualitative and primary data sources obtained through observation, interviews and documentation. The results of this study indicate that the use of the TikTok application by Buddhist youth in Mojorejo Village is caused; entertainment, seeking information and keeping up with the times. The positive impact of the TikTok application is being confident, active, increasing knowledge. In addition, the negative impacts that arise are difficulty managing time, the emergence of a sense of laziness, and difficulty controlling emotions. Narcissistic behavior is shown by Buddhist adolescents from the desire to have many followers, and aggression as a response when getting reprimanded.
\end{abstract}

Keywords: Buddhist Youth, Narcissists, TikTok 


\section{PENDAHULUAN}

Remaja merupakan perkembangan anakanak menuju dewasa, rentang usia remaja adalah $12-21$ tahun yang terbagi menjadi tiga fase yaitu: remaja awal, pertengahan dan akhir (Santrock, 2002:23). Akibat dari banyaknya perubahan yang terjadi pada remaja, juga memunculkan masalah baik yang bersumber dari dalam diri, keluarga, teman sebaya dan lingkungan sosial atau masyarakat. Permasalahan yang terjadi dapat berupa pencarian jati diri atau identitas pribadi. Berada dalam masa peralihan dan memiliki aktualisasi diri yang berbeda-beda, salah satunya ditampilkan melalui perilaku narsistik yang bertujuan untuk mendapatkan pengakuan dari orang lain. Banyak remaja yang menampilkan perilaku narsistik sebagai tindakan mereka dalam pencarian jati diri untuk diakui dalam masyarakat. Perilaku narsistik digambarkan sebagai rasa percaya diri yang berlebihan. Perilaku narsistik remaja banyak ditampilkan melalui aplikasi TikTok yang berupa konten video.

Sedangkan, perilaku remaja Buddhis yang berada juga termasuk pengguna media sosial seperti aplikasi TikTok, yang dimana hal ini berdampak bagi perilaku remaja yang ingin mendapatkan perhatian lebih dari pengguna media sosial lain, dikarenakan dewasa ini kepopuleran lebih penting dari pada perilaku yang baik. Hal ini sangat bertentangan dengan perilaku Buddhis yang menerapkan seorang remaja harus berpedoman kepada Pancasila Buddhis dan juga etika yang diajarkan di dalam Agama Buddha. Seperti halnya remaja Buddhis yang berada di Desa Mojorejo sudah mengalami penurunan moralitas. Yang biasanya remaja Buddhis di Desa Mojorejo aktif dalam kegiatan keagamaan seperti membantu perayaan ataupun berkontribusi dalam kegiatan keagamaan.

Dari uraian tersebut dan berdasarkan fenomena yang terjadi, penulis ingin mengetahui perilaku narsistik ini terjadi pada remaja Buddhis, maka dilakukan penelitian dengan Judul "Analisis Perilaku Narsistik Remaja Buddhis Pengguna Aplikasi TikTok Di Desa Mojorejo, Kecamatan Junrejo, Kota Batu, Jawa Timur". Tujuan penelitian ini mengetahui sebab penggunaan dan dampak aplikasi TikTok bagi remaja Buddhis dan keterkaitan penggunaan aplikasi TikTok dengan perilaku narsistik remaja Buddhis di Desa Mojorejo.

\section{METODE}

Pendekatan yang digunakan dalam penelitian ini adalah kualitatif. Panelitian kualitatif adalah penelitian yang bertujuan untuk memahami fenomena yang terjadi pada subjek penelitian, melalui pengumpulan data secara langsung ke lokasi untuk memperoleh data yang lebih valid (Moleong, 2007:6). Sumber data dalam penelitian kualitatif adalah kata-kata yang diperoleh dari wawancara dan tindakan yang diperoleh dari observasi langsung, terdapat pula sumber data tertulis atau foto yang merupakan data tambahan (Muhadjir, 1996:112). Fokus dari penelitian ini adalah untuk mengetahui perilaku narsistik remaja Buddhis melalui media sosial Aplikasi TikTok, yang berupa penyebab, dampak dan analisis perilaku narsistik remaja Buddhis di Desa Mojorejo, Kecamatan Junrejo, Kota Batu, Jawa Timur.

Penelitian ini menggunakan teknik purposive sampling dalam menentukan informan. Purposive sampling adalah teknik pengambilan sampel dengan kriteria tertentu, yang di mana kriteria tersebut ditentukan oleh peneliti (Sugiyono, 2015:301). Informan dalam penelitian ini adalah ketua remaja Buddhis, orang tua remaja Buddhis, remaja Buddhis dan teman sebaya.

Teknik pengumpulan data dalam penelitian ini menggunakan observasi, wawancara dan dokumentasi. Metode wawancara yang digunakan dalam penelitian ini adalah semi terstruktur, juga dilakukan pengodean (coding) terhadap data-data yang diperoleh baik melalui wawancara, observasi dan dokumentasi. Sedangkan Teknik analisis data yang digunakan dalam penelitian ini yakni: Kondensasi Data (Data Condensation), Penyajian Data (Data Display), dan Verifikasi dan Penarikan Kesimpulan (Conclusion and Verification) (Huberman dan Saldana, 2014:31).

\section{HASIL}

Lokasi dari penelitian ini berada di Desa Mojorejo, Kecamatan Junrejo, Kota Batu, Jawa Timur. Desa Mojorejo merupakan desa yang memiliki perekonomian yang cukup dan memiliki masyarat yang memeluk agama Buddha cukup 
banyak yakni 286 orang. Remaja Buddhis adalah remaja yang menyatakan dirinya beragama Buddha dan berlindung kepada Tiratana (Buddha, Dhamma, Sañgha) dan menjalankan Pañcasīla Buddhis (Sutikno, 2015:22). Remaja Buddhis merupakan salah satu umat awam dalam Agama Buddha, yang biasa disebut dengan Upāsaka (lakilaki) dan Upāsikā (perempuan).

Penjelasan mengenai Upāsaka juga dijelaskan dalam Mahānāma Sutta, AN. $V$., yakni seseorang yang menyatakan pergi berlindung kepada Buddha, Dahmma dan Sangha (Bodhi, 2015:285). Lima latihan moral (pañcasīla) ini merupakan latihan yang wajib dilatih oleh umat perumah tangga. Lima latihan moral adalah sebagai berikut: (1) Menghindari melakukan pembunuhan, (2) Menghindari melakukan pencurian, (3) Menghindari melakukan tindakan asusila, (4) Menghindari mengucapkan kalimat kasar atau kebohongan, dan (5) Menghindari meminum minuman yang menyebabkan lemahnya kesadaran (Sakyaputra, samanaputta.blogspot.com 13 September 2018).

Remaja Buddhis yang ada di Desa Mojorejo juga aktif dalam kegiatan keagamaan yang dilakukan di Vihara Dhammadipa Arama, seperti ikut serta pada perayaan keagamaan dan juga sekolah minggu Buddhis. Sekolah Minggu Buddhis (SMB) merupakan suatu pendidikan nonformal yang diadakan pada hari Minggu untuk umat Buddha sejak usia dini hingga remaja (Wijoyo dan Girivirya, 2020:40). Tidak hanya aktif di kegiatan vihara, remaja Buddhis juga aktif pada kegiatan organisasi dimana terdapat organisasi bagi remaja Buddhis yakni PATRIA (Pemuda Theravada Indonesia) dan mengadakan kegiatan puja bakti bersama di rumah umat setiap hari Sabtu. Puja bakti juga sarana untuk menunjukkan keyakinan (saddha) pada agamanya (Acep, 2018:43).

Memiliki keaktifan pada kegiatan keagamaan baik berupa di vihara maupun diorganisasi, remaja Buddhis di Desa Mojorejo memiliki perilaku yang tidak menyimpang dari norma keagamaan yakni tidak melanggar Pañcasīla Buddhis. Remaja Buddhis juga menerapkan perilaku yang saling menghormati. Tidak hanya pada orang tua atau pada warga desa yang bergama Buddha, akan tetapi juga diterapkan kepada teman sebaya dan masyarakat umum. Hal ini dinyatakan oleh informan dimana remaja Buddhis saling menghargai teman sebaya dan tidak terpengaruh pada media sosial ketika sedang bersama, memiliki rasa toleransi yang tinggi terhadap warga sekitar yang berbeda agama.

Remaja Buddhis juga merupakan remaja yang sedang mengalami pencarian jati diri di masyarakat dan tentunya juga aktif dalam pergaulan baik pergaulan di lingkungan setempat maupun pergaulan di media sosial. Adanya pergaulan di media sosial menjadikan remaja Buddhis juga mengenal aplikasi TikTok yang merupakan aplikasi berbagi video yang terkenal dewasa ini tidak hanya di Indonesia, tapi di seluruh dunia. TikTok pertama diluncurkan pada September 2016 dan merupakan media sosial serta platform video musik Tiongkok yang juga dikenal dengan sebutan Douyin. Aplikasi ini memberikan berbagai efek menarik yang dapat digunakan oleh pengguna dalam video pendek baik bernyanyi atau menari dengan durasi 15 detik sampai 1 menit. Video pendek yang dibuat oleh pengguna dan di dukung dengan efek yang keren dapat menghibur dan menarik perhatian banyak orang yang melihatnya (Rantung, Kompas.com, 15 Februari 2020).

Remaja Buddhis di Desa Mojorejo merupakan pengguna aktif aplikasi TikTok, dimana terdapat beberapa sebab penggunaan aplikasi TikTok oleh remaja Buddhis yang dinyatakan oleh informan. Penggunaan aplikasi TikTok bagi remaja Buddhis di Desa Mojorejo memiliki beberapa sebab. Sebab yang pertama adalah sebagai sarana untuk tidak ketinggalan jaman, dimana semakin canggihnya teknologi maka semakim maraknya aplikasi yang bermunculan. Hal ini yang menjadikan remaja Buddhis perlu untuk mengikuti perkembangan zaman. Kedua, sebagai sarana untuk mencari informasi, dimana terdapat beberapa pengguna aplikasi TikTok menggunakan akunnya untuk berbagi pengetahuan salah satunya seperti tutorial, baik tutorial memasak, membuat barang-barang kreatif atau hal lainnya. Ketiga, aplikasi TikTok digunakan untuk sarana hiburan atau bersenangsenang dan menghilangkan rasa lelah setelah sekolah atau belajar, tidak sedikit pula pengguna aplikasi TikTok yang menggunggah konten video yang menghibur contohnya seperti konten menari, menyanyi atau konten video yang mememiliki humor. 
Sama halnya dengan media sosial lain, aplikasi TikTok juga memberikan dampak positif dan negatif. Dampak positif yang diberikan dapat berupa inovasi, meningkatkan kreatifitas, tersalurnya bakat yang dimiliki para pembuat konten TikTok. Akan tetapi terdapat pula dampak negatif yang ditimbulkan berupa kesulitan mengatur waktu karena kesenangan pada saat mengoperasikan aplikasi TikTok, sebagai ajang untuk menentukan kedudukan sosial dan menyombongkan diri, serta hoaks yang disebarkan. Remaja Buddhis di Desa Mojorejo juga pengguna aktif aplikasi TikTok juga merasakan dampak negatif dan postif. Diketahui bahwa dampak positif yang dirasakan adalah meningkatnya rasa percaya diri, keaktifan serta informasi yang menambah pengetahuan. Akan tetapi terdapat pula dampak negatif yang dirasakan, berupa kesulitan dalam mengatur waktu, timbulnya rasa malas untuk berkativitas, dan kesulitan dalam mengontrol emosi.

Penggunaan aplikasi TikTok oleh remaja Buddhis tidak hanya membawa dampak postif dan dampak negatif, akan tetapi juga membawa perilaku narsistik. Perilaku narsistik dijelasakan Freud dalam teorinya menggunakan istilah narsistik untuk mendeskripsikan orang yang memiliki kecenderungan yang menunjukkan dirinya sebagai orang penting dan perlu untuk diperhatikan (Freud dalam Engkus dkk, 2017: 124). Seseorang yang memiliki perilaku narsistik senantiasa berpusat pada dirinya (self-centered) dan memikirkan dirinya (self-concered), hal ini yang menjadikan seseorang yang memiliki perilaku narsistik selalu mengutamakan keinginannya (Santrock, 2011:437). Perilaku narsistik juga dapat diwujudkan baik dalam bentuk gerak maupun ucapan yang ditujukan pada diri sendiri (Nurahmi dan Oktaviani, 2018:71).

Perilaku narsistik merupakan perilaku yang dimana seseorang mencoba untuk mendapatkan perhatian dan menonjolkan dirinya. Perilaku ini tentunya tidak muncul secara tiba-tiba, dimana terdapat faktor yang mempengaruhinya. Berikut ini adalah penyebab adanya perilaku narsistik: (1) Memiliki karakter yang tempramen dan sensitif, (2) Mendapat pujian dan penilaian yang berlebihan dari orang tua, (3) Penilaian orang tua sebagai tujuan untuk mengatur harga diri mereka, (4) Mendapat sanjungan atau pujian yang tidak sesuai dengan realita, (5) Pemberian perhatian yang tidak terduga secara berlebihan dari orang tua, (6) Kebanggaan terhadap bakat dan penampilan (Barlow dan Durand, 2006:212).

Bagi pengguna aplikasi TikTok kebanyakkan tidak menyadari bahwa menggunakan aplikasi TikTok tidak menimbulkan sifat narsistik. Akan tetapi tanpa disadari sifat narsistik dapat muncul ketika pengguna menginginkan like, followers dan komentar yang banyak dan membuat pengguna tersebut dikenal lebih banyak pengguna aplikasi TikTok lainnya. Dimana hal ini selaras dengan kecenderungan narsistik berdasarkan DSM-IV (Diagnostic and Statistical Manual of Mental Disorders-Fourth Edition) yakni keinginan untuk mendaptkan penghargaan diri dari orang lain. kecenderungan narsistik yang terjadi pada remaja Buddhis di Desa Mojorejo adalah memiliki persaan iri pada orang lain atau anggapan bahwa orang lain iri pada yang dimiliki (Santi, 2017:28). Dimana hal ini sesuai yang dinyatakan oleh informan dimana remaja Buddhis ketika berkumpul akan saling membandingkan berapa banyak followers yang dimiliki. Perilaku narsistik remaja Buddhis di Desa Mojorejo juga ditunjukkan dengan cara aktif dalam membuat konten video dan membagikannya di media sosial yang lain.

Perilaku narsistik remaja Buddhis di Desa Mojorejo juga memberikan dampak negatif kepada remaja Buddhis itu sendiri. Dampak narsistik yang dirasakan adalah kesulitan untuk mengendalikan emosi dan mudah sensitif selaras dengan dampak dari kecenderungan narsistik berdasarkan penelitian Sakinah, Zatrahadi dan Darmawati (2019:36-38) yakni agresi, individu yang memiliki kecenderungan narsistik akan mudah marah, dan kecewa. Dimana hal tersebut merupakan respon terhadap kegagalan atau kritikan dari orang lain.

Membandingkan berapa banyak followers atau like yang dilakukan oleh remaja Buddhis ini menunjukkan adanya iri atau cemburu, yang dimana hal ini merupakan sifat yang buruk yakni issā (iri hati). Dimana perasaan iri hanya akan membawa pada kamma buruk yang akan mengakibatkan penderitaan baik kehidupan sekarang maupun yang akan datang. Jika remaja Buddhis tidak memiliki perasaan iri melainkan simpatik (muditā), maka tidak akan timbulnya rasa iri dan tindakan untuk membandingkan dengan yang lain. Selain memiliki perasaan iri terhadap 
orang lain, penggunaan aplikasi TikTok oleh remaja Buddhis di Desa Mojorejo menyebabkan kesulitan untuk mengotrol emosi atau mudah marah. Dimana hal ini tidak sesuai dengan ajaran Sang Buddha untuk selalu memancarakan metta (cinta kasih universal). Jika remaja Buddhis di Desa Mojorejo dapat memancarakn metta, maka tidak akan muncul emosi kitika mendapat kritikan atau teguran karena kesalahan.

\section{KESIMPULAN}

Keinginan untuk menampilkan jadi diri di masayarakat membuat remaja memiliki perilaku narsistik yang ditampilan melalui aplikasi TikTok dengan konten video. Hal yang sama juga dilakukan oleh remaja Buddhis di Desa Mojorejo, dimana penggunaan aplikasi TikTok untuk hiburan, bersenang - senang, mencari informasi dan agar tidak ketinggalan jaman. Akan tetapi penggunaanya memberikan dampak positif yang dirasakan adalah remaja menjadi lebih percaya diri, lebih aktif dalam bergerak, lebih kreatif, mengakses informasi, mendapatkan tips atau trik dan melatih bahasa asing. Sedangkan dampak negatif yang dirasakan adalah kesulitan dalam mengatur waktu, timbulnya rasa malas untuk berkativitas, dan kesulitan dalam mengontrol emosi. Penggunaan aplikasi TikTok juga menimbulkan perilaku narsistik pada remaja Buddhis, hal ini ditunjukkan dari remaja Buddhis yang membandingkan berapa banyak followers yang didapatkan dengan remaja Buddhis lain. keinginan untuk memiliki banyak followers, sesuai dengan kecenderungan narsistik yang memiliki keinginan untuk diperhatikan, penghargaan diri dari orang lain. Remaja Buddhis juga menunjukkan agresi berupa kesal, marah dan sensitif sebagai respon ketika mendapt kritikan atau teguran dari orang lain. Respon yang diperlihatkan oleh remaja Buddhis ketika mendapat kritik atau teguran, tidak bertentangan dengan dampak dari kecenderungan narsistik.

\section{Daftar Pustaka}

1. Acep, Lauw. 2018. Kecerdasan Spiritual dan Puja Bakti. Jurnal Dhammavicaya. Volume II, No. 1. Hal 40-51.

2. Bodhi. 2015. Anguttara Nikāya KhotbahKhotbah Numerikal Sang Buddha: Jilid 3
Buku Kelompok 5 - 6. Jakarta: DhammaCitta Press.

3. Damayanti, Trie dan Gemiharto, Ilham. 2019. Kajian Dampak Negatif Aplikasi Berbagi Video Bagi Anak-Anak di Bawah Umur di Indonesia. Communication. Volume 10 No. 1. Hal. 1-15.

4. Durand, V. M. dan David H. Barlow. 2006. Psikologi Abnormal. Yogyakarta: Pustaka Belajar.

5. Engkus, Hikmat dan Karso S. 2017. Perilaku Narsis Pada Media Sosial Di Kalangan Remaja dan Upaya Penanggulangannya. Jurnal Penelitian Komunikasi. Volume 20 No. 2, Hal. 121134.

6. Miles, M. B., Huberman, A. M. dan Saldana J. 2014. Qualitative Data Analysis, A Methods Sourcebook, Edition 3. Terj. Tjeptjep Rohindi Rohidi. Jakarta: UI Press.

7. Moleong, Lexy J. 2007. Metodologi Penelitian Kualitatif. Bandung: PT. Remaja Rosdakarya.

8. Muhadjir, Neong. 1996. Metodologi Penelitian Kualitatif. Yogyakarta: Rake Sarasisn.

9. Nurahmi, H. dan Oktaviani, E. R. 2018. Bimbingan Dan Konseling Islam Pada Berperilaku Kecenderungan Narsis Di Kelas XI MAN 2 Pontianak. Jurnal Dakwah. Volume 12 No. 1, Hal. 65-82.

10. Sakinah, U., Zatrahadi, Fahli M., dan Darmawati. 2019. Fenomena Natsistik di Media Sosial Sebagai Bentuk Pengakuan Diri. Al-Ittizaan: Jurnal Bimbingan Konseling Islam. Volume 2 No. 1, Hal 3443.

11. Santi, Novi Nitya. 2017. Dampak Kecenderungan Narsiscisme Terhadap Self Esteem pada Pengguna Facebook Mahasiswa PGSD UNP. Jurnal Dimensi Pendidikan dan Pembelajaran. Volume 5 No. 1, Hal. 25-30.

12. Santrock, John W. 2002. Adolesence Perkembangan Remaja. Jakrta: Erlangga.

13. 2011.Perkembangan Anak

Edisi 7 Jilid 2. Jakarta: Erlangga.

14. Sugiyono. 2015. Metode Penelitian Kombinasi (Mix Methods). Bandung: Alfabeta. 
15. Sutikno. 2015. Skripsi Pengaruh Kegiatan Dhamma Camp Terhadap Keyakinan Dhamma Remaja Buddhis di Dusun Kagok, Grobogan, Jawa Tengah. Batu: STAB Kertarajasa.

16. Wijoyo, Hadion dan Sulaiman Girivirya. 2020. Pengaruh Sekolah Minggu Buddha (SMB) Terhadap Perkembangan FisikMotorik Peserta Didik di SMB Sariputta Buddhist Studies Pekanbaru. Jurnal Maitreyawira. Volume 1 No. 1, Hal. 3952.

Sumber Internet:

17. Rantung, Revi C. 2020. 5 Lagu yang Populer di Aplikasi TikTok 2020, dari Any Soanghingga Tari UburUbur. https://www.kompas.com/hype/read/2020 /02/15/112818166/5-lagu-yang-populerdi-tiktok-2020-dari-any-song-hingga-tariubur-ubur?page=all. (Diakses 13 Februari 2021 pkl 15:14 WIB).

18. Sakyaputra, Saputra. 13 September 2018. Pengertian Upāsaka / Upāsikā dan Cara 